2011-04-01

\title{
Measured Performance of a 1.72 kW Rooftop Grid Connected Photovoltaic System in Ireland
}

\author{
Lacour Ayompe \\ Technological University Dublin, lacour.ayompe@tudublin.ie \\ Aidan Duffy \\ Technological University Dublin, aidan.duffy@tudublin.ie \\ Sarah McCormack \\ Trinity College Dublin, mccorms1@tcd.ie
}

See next page for additional authors

Follow this and additional works at: https://arrow.tudublin.ie/engschcivart

Part of the Power and Energy Commons

\section{Recommended Citation}

Ayompe, L., Duffy, A., McCormack, S., Conlon, M., (2011) Measured performance of a 1.72 kW rooftop grid connected photovoltaic system in Ireland, Energy Conversion and Management, Volume 52, Issue 2, Pages 816-825, ISSN 0196-8904. doi:10.1016/j.enconman.2010.08.007

This Article is brought to you for free and open access by the School of Civil and Structural Engineering at ARROW@TU Dublin. It has been accepted for inclusion in Articles by an authorized administrator of ARROW@TU

Dublin. For more information, please contact

arrow.admin@tudublin.ie, aisling.coyne@tudublin.ie, gerard.connolly@tudublin.ie.

Funder: Higher Education Authority TSR Strand 3

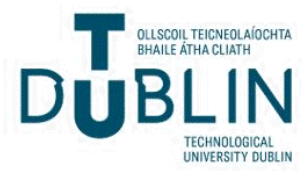




\section{Authors}

Lacour Ayompe, Aidan Duffy, Sarah McCormack, and Michael Conlon 


\section{AUTHOR QUERY FORM}

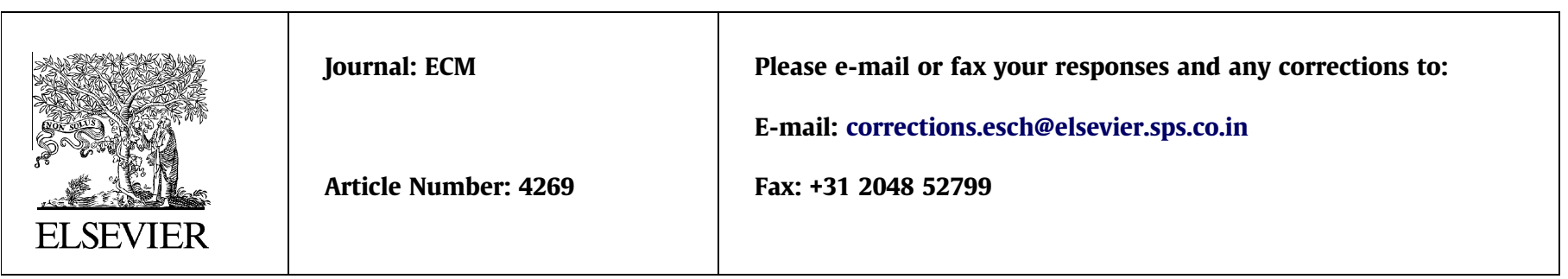

Dear Author,

Please check your proof carefully and mark all corrections at the appropriate place in the proof (e.g., by using on-screen annotation in the PDF file) or compile them in a separate list.

For correction or revision of any artwork, please consult http://www.elsevier.com/artworkinstructions.

Any queries or remarks that have arisen during the processing of your manuscript are listed below and highlighted by flags in the proof. Click on the ' $Q$ ' link to go to the location in the proof.

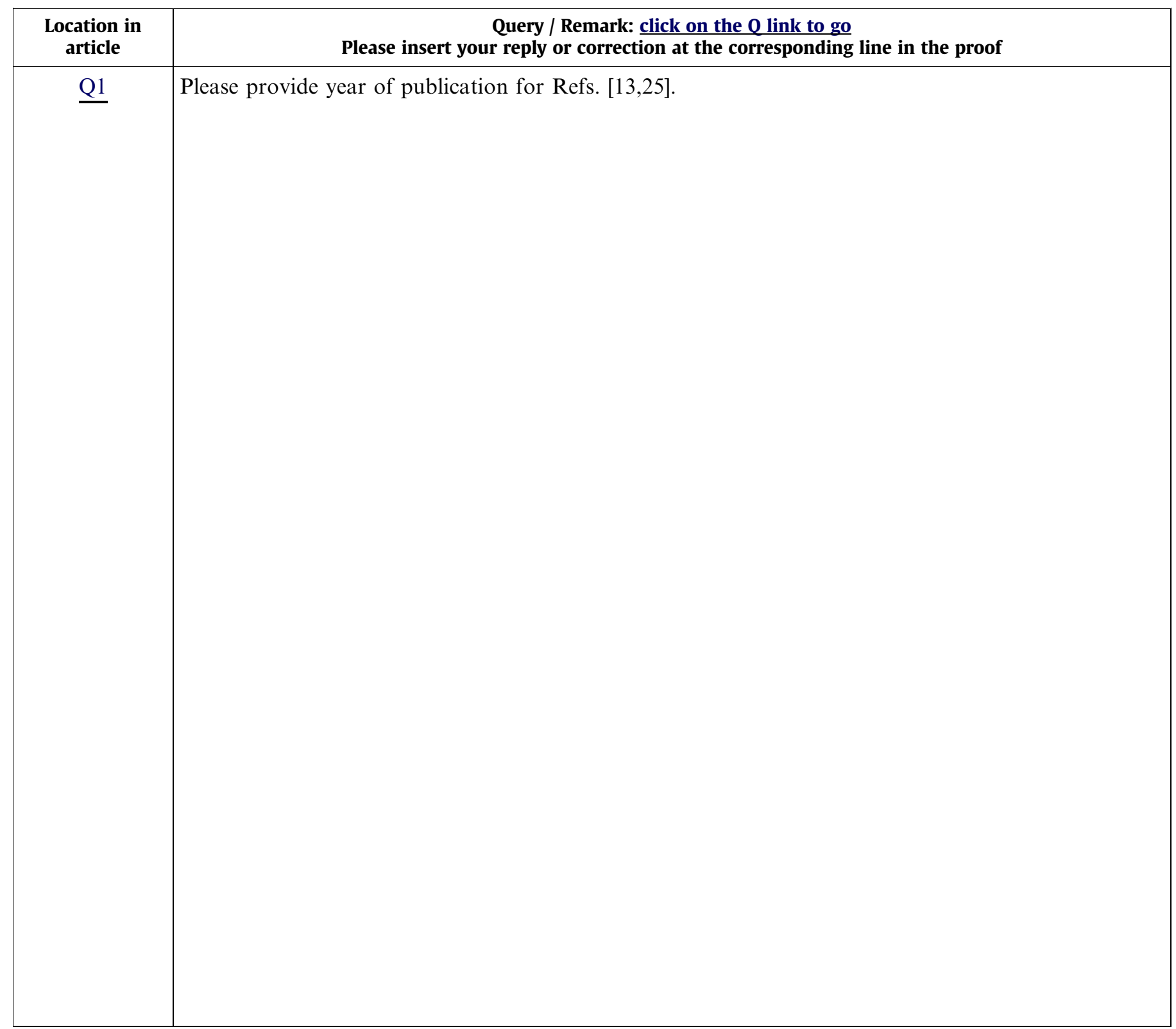

Thank you for your assistance. 


\title{
Measured performance of a $1.72 \mathrm{~kW}$ rooftop grid connected photovoltaic system in Ireland
}

\author{
L.M. Ayompe ${ }^{\mathrm{a}, *}$, A. Duffy ${ }^{\mathrm{a}}$, S.J. McCormack ${ }^{\mathrm{b}}$, M. Conlon ${ }^{\mathrm{c}}$ \\ ${ }^{a}$ Department of Civil and Structural Engineering, School of Civil and Building Services, Dublin Institute of Technology, Bolton Street, Dublin 1, Ireland \\ ${ }^{\mathrm{b}}$ Department of Civil, Structural and Environmental Engineering, Trinity College, Dublin 8, Ireland \\ ' School of Electrical Engineering Systems, Dublin Institute of Technology, Kevin St, Dublin 8, Ireland
}

\section{A R T I C L E I N F O}

\section{Article history:}

Received 23 December 2009

Accepted 8 August 2010

Available online $\mathrm{xxxx}$

\section{Keywords:}

Photovoltaics

Grid connected

Final yield

PV module efficiency

Inverter efficiency

Performance ratio

\begin{abstract}
A B S T R A C T
This paper presents results obtained from monitoring a $1.72 \mathrm{~kW}_{\mathrm{p}}$ photovoltaic system installed on a flat roof of a $12 \mathrm{~m}$ high building in Dublin, Ireland (latitude $53.4^{\circ} \mathrm{N}$ and longitude $6.3^{\circ} \mathrm{E}$ ). The system was monitored between November 2008 and October 2009 and all the electricity generated was fed into the low voltage supply to the building. Monthly average daily and annual performance parameters of the PV system evaluated include: final yield, reference yield, array yield, system losses, array capture losses, cell temperature losses, PV module efficiency, system efficiency, inverter efficiency, performance ratio and capacity factor. The maximum solar radiation, ambient temperature and PV module temperature recorded were $1241 \mathrm{~W} / \mathrm{m}^{2}$ in March, $29.5^{\circ} \mathrm{C}$ and $46.9{ }^{\circ} \mathrm{C}$ in June respectively.

The annual total energy generated was $885.1 \mathrm{~kW} h / \mathrm{kW}_{\mathrm{p}}$ while the annual average daily final yield, reference yield and array yield were $2.41 \mathrm{~kW} h \hat{\mathrm{h}} / \mathrm{kW}_{\mathrm{p}} /$ day, $2.85 \mathrm{kWh} / \mathrm{kW}_{\mathrm{p}} /$ day and $2.62 \mathrm{~kW} \mathrm{~h} / \mathrm{kW}_{\mathrm{p}} /$ day respectively. The annual average daily $\mathrm{PV}$ module efficiency, system efficiency and inverter efficiency were $14.9 \%, 12.6 \%$ and $89.2 \%$ respectively while the annual average daily performance ratio and capacity factor were $81.5 \%$ and $10.1 \%$ respectively. The annual average daily system losses, capture losses and cell temperature losses were $0.23 \mathrm{~h} /$ day, $0.22 \mathrm{~h} /$ day and $0.00 \mathrm{~h} /$ day respectively.

Comparison of this system with other systems in different locations showed that the system had the highest annual average daily PV module efficiency, system efficiency and performance ratio of $14.9 \%$, $12.6 \%$ and $81.5 \%$ respectively. The PV system's annual average daily final yield of $2.4 \mathrm{~kW} \mathrm{h/kW} /$ / day is higher than those reported in Germany, Poland and Northern Ireland. It is comparable to results from some parts of Spain but it is lower than the reported yields in most parts of Italy and Spain. Despite low insolation levels, high average wind speeds and low ambient temperature improve Ireland's suitability.
\end{abstract}

(c) 2010 Elsevier Ltd. All rights reserved.
Electricity generation using photovoltaic (PV) systems is important, reliable and has the potential to play a significant role in $\mathrm{CO}_{2}$ emissions mitigation [1]. It is widely accepted that PV will become one of the major future sources of electricity generation considering the potential for cost reduction of PV systems and grid-parity expected in Southern and Northern Europe around 2020 [2]. Global PV electricity generating technology has sustained an impressive annual growth rate compared with other renewable energy generating technologies. Total global installed capacity of grid connected solar PV was $3.5 \mathrm{GW}_{\mathrm{p}}, 5.1 \mathrm{GW}_{\mathrm{p}}, 7.5 \mathrm{GW}_{\mathrm{p}}$ and $13 \mathrm{GW}_{\mathrm{p}}$ in 2005 , 2006, 2007 and 2008 respectively [3]. Despite this impressive growth, Ireland still lags with virtually little or no installations. In 2008, the cumulative installed PV capacity in Ireland was $0.4 \mathrm{MW}_{\mathrm{p}}$ made up of $0.1 \mathrm{MW}_{\mathrm{p}}$ and $0.3 \mathrm{MW}_{\mathrm{p}}$ of grid-connected and off-grid capacity respectively. The installed photovoltaic power per inhabitant in Ireland was $0.09 \mathrm{~W}_{\mathrm{p}}$ /inhabitant while the EU 27 average was $19.2 \mathrm{~W}_{\mathrm{p}} /$ inhabitant [4].

\footnotetext{
Corresponding author. Tel.: +353 14022997

E-mail address: lacour.ayompe@dit.ie (L.M. Ayompe).
} 


\section{Nomenclature}

$A_{\mathrm{a}} \quad$ PV array area $\left(\mathrm{m}^{2}\right)$

$\mathrm{AC} \quad$ alternating current (A)

CF capacity factor (\%)

DC direct current (A)

$E_{\mathrm{AC}} \quad$ AC energy output $(\mathrm{kW} \mathrm{h})$

$E_{\mathrm{QC}, \mathrm{d}} \quad$ total daily total DC energy output $(\mathrm{kW} \mathrm{h})$

$E_{\mathrm{AC}, \mathrm{d}} \quad$ total daily total AC energy output $(\mathrm{kW} \mathrm{h})$

$E_{\mathrm{AC}, \mathrm{m}} \quad$ total monthly $\mathrm{AC}$ energy output $(\mathrm{kW} \mathrm{h})$

$E_{\mathrm{AC}, \mathrm{a}} \quad$ total annual AC energy output $(\mathrm{kW} h)$

$\bar{E}_{\mathrm{AC}, \mathrm{d}} \quad$ monthly average daily total AC output (kW h)

$\bar{E}_{\mathrm{DC}, \mathrm{d}} \quad$ monthly average daily total DC output (kW h)

$E_{\text {ideal }}$ energy generated at rated power $(\mathrm{kWh})$

$E_{\text {real }} \quad$ energy generated during operation $(\mathrm{kW} \mathrm{h})$

$G_{\text {STC }}$ total solar radiation under standard test conditions $\left(\mathrm{KW} / \mathrm{m}^{2}\right)$

$G_{\mathrm{t}} \quad$ total in-plane solar radiation $\left(\mathrm{W} / \mathrm{m}^{2}\right)$

$H_{\mathrm{t}} \quad$ total in-plane solar insolation $\left(\mathrm{kW} \mathrm{h} / \mathrm{m}^{2}\right)$

$L_{\mathrm{c}} \quad$ capture losses (h/day)

$L_{\mathrm{s}} \quad$ system losses (h/day)
$L_{\mathrm{T}} \quad$ cell temperature losses (h/day)

$P_{\text {AC }} \quad$ AC power $(\mathrm{kW})$

$P_{\mathrm{DC}} \quad$ DC power $(\mathrm{kW})$

$P_{\mathrm{DC}, \mathrm{STC}} \quad$ DC power under standard test conditions $(\mathrm{kW})$

$P_{\mathrm{PV}, \text { rated }} \quad \mathrm{PV}$ rated power $\left(\mathrm{kW}_{\mathrm{p}}\right)$

$\mathrm{PR}$ performance ratio (\%)

$Y_{\mathrm{A}} \quad$ array yield $\left(\mathrm{kWh} / \mathrm{kW}_{\mathrm{p}}\right)$

$Y_{\mathrm{F}} \quad$ final yield $\left(\mathrm{kW} \mathrm{h} / \mathrm{kW}_{\mathrm{p}}\right)$

$Y_{\mathrm{R}} \quad$ reference yield $\left(\mathrm{kW} \mathrm{h} / \mathrm{kW}_{\mathrm{p}}\right)$

$\eta \quad$ efficiency (\%)

Subscripts

deg degradation

m monthly

inv inverter

PV photovoltaic module

soil soiling

sys system

STC standard test conditions

temp temperature
In April 2008, the Irish Government announced a new micro and small scale electricity generation programme for Ireland. Fifty pilot trial micro-generation installations were due to be installed in 2009 with an average plant size of $1.25 \mathrm{~kW}_{\mathrm{p}}$ [5]. This communiqué highlighted the Irish Government's desire to implement a microgeneration programme. In February 2009, the Irish Government announced the implementation of a feed-in-tariff of $19 €$ cents per kW h for electricity from micro-generation [6]. For such a programme to be successfully implemented, it is imperative that both field trials to provide information on the annual energy yield of typical installations and studies to determine the economics as well as environmental benefits of PV systems in Ireland be undertaken for informed policy implementation.

The aim of this paper is to present results obtained from field performance monitoring of a $1.72 \mathrm{~kW}$ roof mounted PV system in Dublin, Ireland. Data collected between November 2008 and October 2009 was analysed to evaluate the suitability of PV systems for installation in residential buildings in Ireland. The PV system is described while different performance evaluation parameters are presented based on collected data. The performance parameters calculated include: annual energy generated, array yield, final yield, reference yield, PV module, system efficiency, inverter efficiency, performance ratio, capacity factor, array capture losses, system losses and cell temperature losses. Results obtained give an indication of system performance and provide a basis for economic and environmental impact appraisal of PV generated electricity and inform policy formulation to promote uptake of the technol- ogy in Ireland. Performance data are compared with those obtained in other locations around Europe and the Middle East.

\section{The PV system}

The PV system was installed on the rooftop of the Focas Institute building, Dublin Institute of Technology, Ireland. It consisted of eight modules covering a total area of $10 \mathrm{~m}^{2}$ with an installed capacity of $1.72 \mathrm{~kW}_{\mathrm{p}}$ within the range of typical domestic installations. The Sanyo HIP-215NHE5 modules were each of $215 \mathrm{~W}_{\mathrm{p}}$ capacity and comprised 72 solar cells made of thin mono-crystalline silicon wafer surrounded by ultra-thin amorphous silicon layers. The modules had an efficiency of $17.2 \%$ under standard test conditions and were connected in series. The unshaded modules were fixed, inclined at an angle of $53^{\circ}$ equal to the latitude of Dublin, facing south at an azimuth angle of $0^{\circ}$. The roof was approximately $12 \mathrm{~m}$ high and the modules were mounted on metal frames that were $1 \mathrm{~m}$ high.

The PV modules were left uncleaned throughout the monitoring period to mimic operation in a domestic dwelling. A single phase Sunny Boy SB 1700 inverter was used to convert DC to AC which was fed directly into the building. The inverter had a rated maximum efficiency of $93.5 \%$ and maximum AC power of $1700 \mathrm{~W}$. The solar irradiation sensor had an accuracy of $\pm 8 \%$ and a resolution of $1 \mathrm{~W} / \mathrm{m}^{2}$. The PV module temperature sensor was a PT $100-\mathrm{M}$ type with accuracy of $\pm 0.5^{\circ} \mathrm{C}$ while the ambient temperature sensor was a JUMO PT $100 \mathrm{U}$ type with accuracy of $\pm 0.5^{\circ} \mathrm{C}$. The ane-
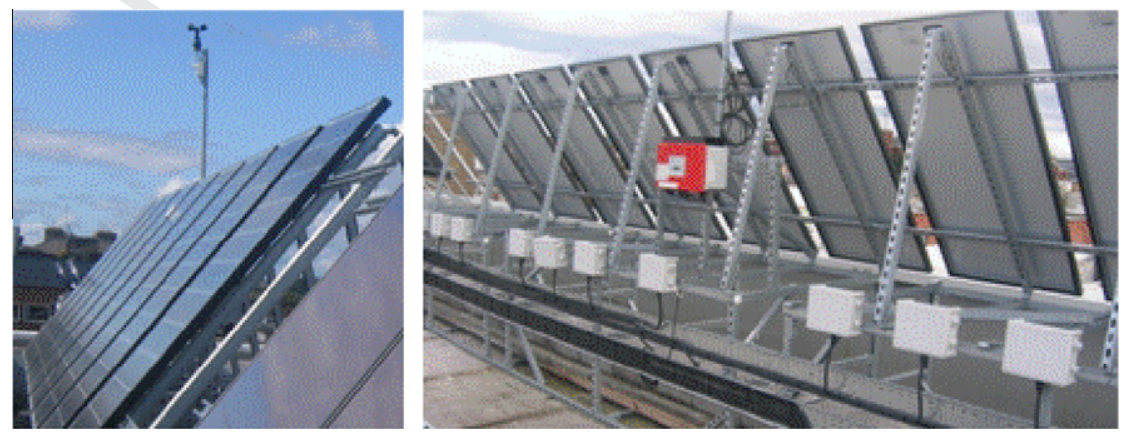

Fig. 1. The PV system installation. 
Table 1

PV modules and array specifications.

\begin{tabular}{ll}
\hline PV module/array & Specification \\
\hline Type & Mono-crystalline silicon \\
Cell efficiency & $19.3 \%$ \\
Module efficiency & $17.2 \%$ \\
Maximum power $\left(P_{\max }\right)$ & $215 \mathrm{~W}$ \\
Maximum power voltage $\left(V_{\mathrm{pm}}\right)$ & $42.0 \mathrm{~V}$ \\
Maximum power current $\left(I_{\mathrm{pm}}\right)$ & $5.13 \mathrm{~A}$ \\
Open circuit voltage $\left(V_{\mathrm{oc}}\right)$ & $51.6 \mathrm{~V}$ \\
Short circuit current $\left(I_{\mathrm{sc}}\right)$ & $5.61 \mathrm{~A}$ \\
Warranted minimum power $\left(P_{\min }\right)$ & $204.3 \mathrm{~W}$ \\
Output power tolerance & $+10 /-5 \%$ \\
Maximum system voltage $\left(V_{\mathrm{dc}}\right)$ & 1000 \\
Temperature coefficient of $P_{\max }$ & $-0.3 \% /{ }^{\circ} \mathrm{C}$ \\
Module area & $1.25 \mathrm{~m}$ \\
No. of modules & 8 \\
NOCT & $45{ }^{\circ} \mathrm{C}$ \\
\hline
\end{tabular}

Table 2

Sunny Boy 1700 inverter specifications.

\begin{tabular}{ll}
\hline Inverter & Specification \\
\hline Input & \\
Maximum dc power & $1850 \mathrm{~W}$ \\
Maximum dc voltage & $400 \mathrm{~V}$ \\
PV - voltage range at MPPT & $139-400 \mathrm{~V}$ \\
Output & \\
Maximum ac power & $1700 \mathrm{~W}$ \\
Nominal ac power & $1550 \mathrm{~W}$ \\
Efficiency & \\
Maximum efficiency & $93.5 \%$ \\
Euro-eta & $91.8 \%$ \\
Weight & $25 \mathrm{~kg}$ \\
\hline
\end{tabular}

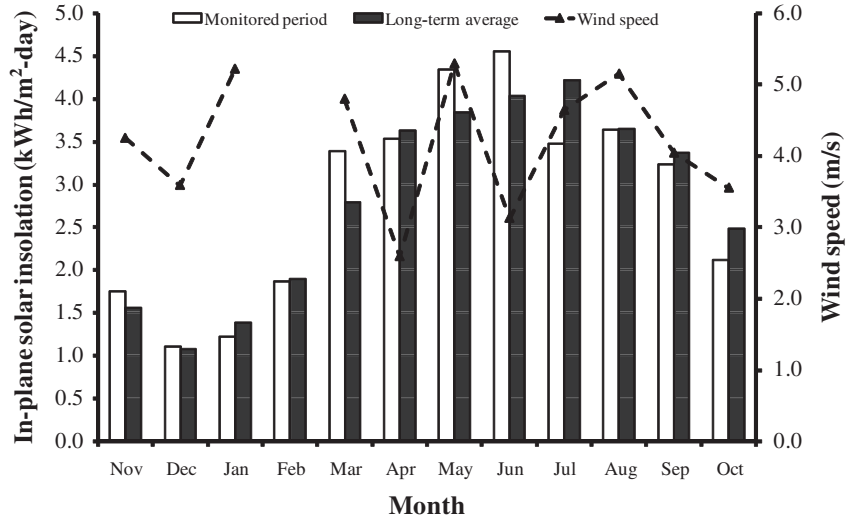

Fig. 3. Monthly average daily total in-plane solar insolation, long-term in-plane average for Dublin and wind speed.

speed and temperature at the back of one of the PV modules were connected to the SensorBox. The SensorBox and inverter were connected to the Sunny WebBox via a serial RS485 link and a Power Injector. Data recorded on 5 min intervals in the WebBox was extracted via an SD card and read directly into a computer.

\section{Monitoring results}

\subsection{Weather data}

Fig. 3 shows monthly average daily total in-plane solar insolation on the PV modules measured from November 2008 to October 2009. The monthly average daily total solar insolation varied from $1.11 \mathrm{kWh} / \mathrm{m}^{2} /$ day in December to $4.56 \mathrm{kWh} / \mathrm{m}^{2} /$ day in June. These values were slightly higher than the corresponding minimum and maximum long-term monthly average daily values of $1.08 \mathrm{~kW} \mathrm{~h} / \mathrm{m}^{2} /$ day and $4.22 \mathrm{~kW} \mathrm{~h} / \mathrm{m}^{2} /$ day in December and July respectively. The annual total measured and long-term in-plane solar insolations were $1043.1 \mathrm{kWh} / \mathrm{m}^{2}$ and $1034.5 \mathrm{kWh} / \mathrm{m}^{2}$ respectively. The monthly average daily wind speed varied between $2.6 \mathrm{~m} / \mathrm{s}$ in April and $5.3 \mathrm{~m} / \mathrm{s}$ in May.

Fig. 4 shows monthly average daily ambient temperature and temperature at the back of one of the PV modules over the monitored period. The monthly average ambient temperature varied between $7.4^{\circ} \mathrm{C}$ in January and $18.9^{\circ} \mathrm{C}$ in August while the PV module temperature varied between $9.9^{\circ} \mathrm{C}$ in January and $24.1{ }^{\circ} \mathrm{C}$ in June. Wind speed and PV module temperature data for February were not available due to a problem with the SensorBox.

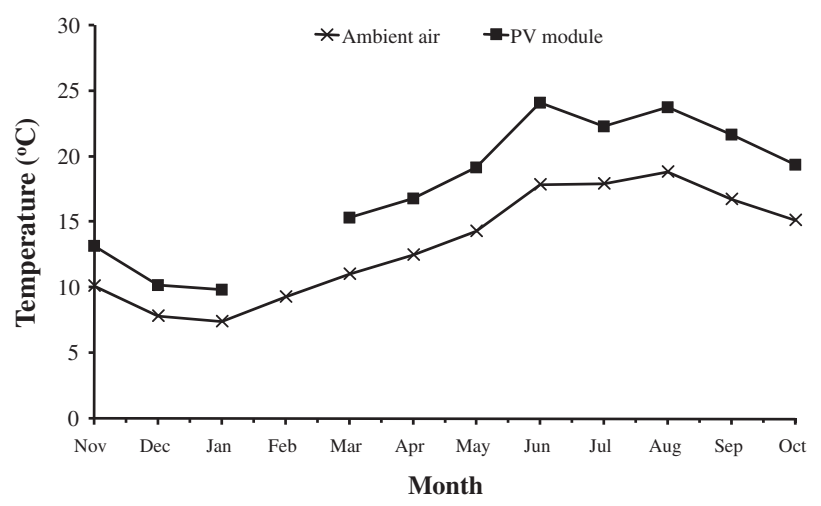

Fig. 4. Monthly average daily ambient air and PV module temperature over the monitored period.

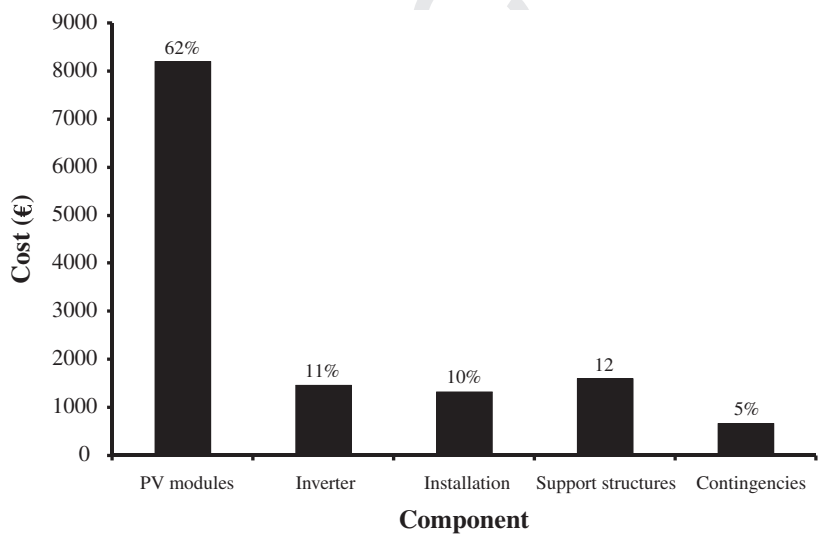

Fig. 2. Cost breakdown of the PV system. 
Table 3

Average ambient air temperature, PV module temperature and wind speed for different levels of solar radiation.

\begin{tabular}{lllll}
\hline $\begin{array}{l}\text { In-plane solar } \\
\text { radiation (W/ } \\
\left.\mathrm{m}^{2}\right)\end{array}$ & $\begin{array}{l}\text { Fraction of } \\
\text { solar radiation } \\
(\%)\end{array}$ & $\begin{array}{l}\text { Ambient } \\
\text { temperature } \\
\left({ }^{\circ} \mathrm{C}\right)\end{array}$ & $\begin{array}{l}\text { PV module } \\
\text { temperature } \\
\left({ }^{\circ} \mathrm{C}\right)\end{array}$ & $\begin{array}{l}\text { Wind } \\
\text { speed } \\
(\mathrm{m} / \mathrm{s})\end{array}$ \\
\hline $0-99$ & 30.3 & 13.9 & 14.3 & 3.6 \\
$100-199$ & 22.6 & 15.4 & 17.9 & 4.1 \\
$200-299$ & 12.8 & 16.0 & 20.6 & 4.3 \\
$300-399$ & 7.9 & 16.0 & 22.1 & 4.5 \\
$400-499$ & 5.9 & 16.0 & 23.7 & 4.7 \\
$500-599$ & 4.9 & 16.2 & 25.5 & 4.7 \\
$600-699$ & 4.2 & 16.5 & 27.5 & 4.8 \\
$700-799$ & 3.8 & 17.5 & 30.2 & 4.7 \\
$800-899$ & 3.8 & 18.1 & 33.3 & 4.4 \\
$900-999$ & 3.0 & 18.3 & 34.8 & 4.6 \\
$1000-1099$ & 0.8 & 16.8 & 30.9 & 5.9 \\
$1100-1199$ & 0.1 & 16.8 & 29.6 & 5.8 \\
$1200-1299$ & 0.0 & 12.1 & 29.0 & 5.8 \\
\hline
\end{tabular}

Table 3 shows the fraction of solar radiation, average ambient air temperature, PV module temperature, and wind speed for different levels of solar radiation between November 2008 and October 2009. The average ambient air temperature varied between $12.1^{\circ} \mathrm{C}$ at $1200-1299 \mathrm{~W} / \mathrm{m}^{2}$ and $18.0^{\circ} \mathrm{C}$ at $900-999 \mathrm{~W} / \mathrm{m}^{2}$. The average $\mathrm{PV}$ module temperature varied between $14.3^{\circ} \mathrm{C}$ at $\mathrm{O}^{\wedge}$ $99 \mathrm{~W} / \mathrm{m}^{2}$ and $34.8{ }^{\circ} \mathrm{C}$ at $900-999 \mathrm{~W} / \mathrm{m}^{2} .92 .3 \%$ of total in-plane solar radiation was below $800 \mathrm{~W} / \mathrm{m}^{2}$ with a maximum average PV module temperature of $22.7^{\circ} \mathrm{C}$ in this solar radiation range. This indicates low influence of high PV module temperature on the PV system's performance. Low average ambient temperatures and high wind speeds provided good operating conditions for the PV system by keeping the average PV module operating temperature lower than the standard operating condition temperature.

\subsection{PV module temperature}

A PT $100 \mathrm{M}$-type temperature sensor was used to measure the temperature at the back surface of one of the PV modules. Fig. 5 shows the variation of average wind speed, ambient air and PV module temperature against different levels of solar radiation. The ambient air and PV module temperatures are seen to generally increase as the level of solar radiation increases. The PV module temperature experienced a higher increase at solar radiation levels between 600 and $999 \mathrm{~W} / \mathrm{m}^{2}$ as a result of lower average wind speeds at these radiation levels. However, higher average wind speeds at solar radiation levels between 1000 and $1299 \mathrm{~W} / \mathrm{m}^{2}$ caused a drop in PV module temperature.

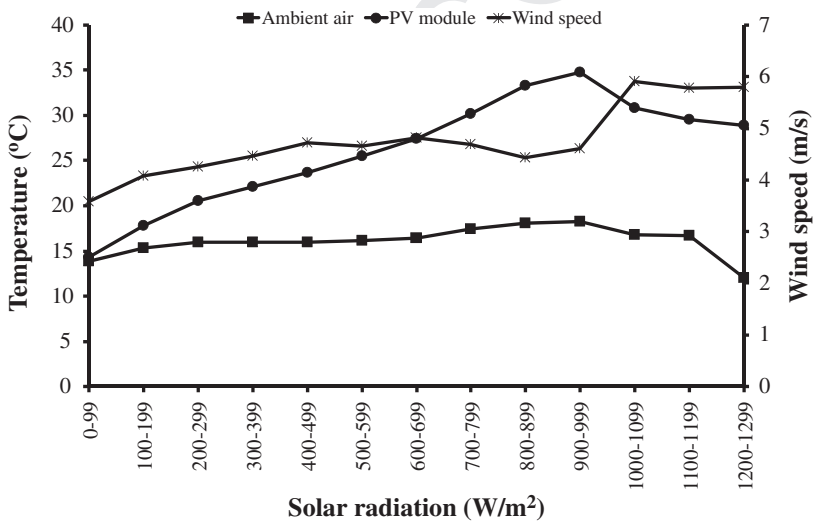

Fig. 5. Average wind speed, ambient air and PV module temperature against different levels of solar radiation over the monitored period.
Table 4 shows monthly ranges variation of solar radiation, PV module temperature, ambient temperature, and the linear correlation coefficient $\left(R^{2}\right)$ between the PV module temperature and the ambient temperature. The average annual $R^{2}$ value of 0.67 however, indicated a fairly wide scatter between the values. This scatter band arises from delayed transient temperature responses to insolation changes and variations in wind speed [7]. High wind speeds, low ambient temperatures, the height of the building (over $12 \mathrm{~m}$ ) on which the PV modules are installed as well as not being roof integrated contributed to lowering the PV module temperature. The maximum temperature difference between the PV module and ambient was $26^{\circ} \mathrm{C}$ and occurred at a solar radiation intensity of $791 \mathrm{~W} / \mathrm{m}^{2}$. The maximum PV module temperature recorded was $46.9{ }^{\circ} \mathrm{C}$ which occurred when the solar radiation intensity, ambient temperature and wind speed were $977.8 \mathrm{~W} / \mathrm{m}^{2}$, $23.6^{\circ} \mathrm{C}$ and $0.92 \mathrm{~m} / \mathrm{s}$ respectively.

\section{Performance analysis}

208

In order to analyse the energy related performance of a grid connected PV system, some important parameters are to be computed using data collected during its operation in a given location. These parameters include: the total energy generated by the PV system $\left(E_{\mathrm{AC}}\right)$, the array yield $\left(Y_{\mathrm{A}}\right)$, final yield $\left(Y_{\mathrm{F}}\right)$, reference yield $\left(Y_{\mathrm{R}}\right)$, performance ratio (PR) and capacity factor $(\mathrm{CF})$. These normalized performance indicators are relevant since they provide a basis under which PV systems can be compared under various operating conditions.

\subsection{Energy output}

The total daily $\left(E_{\mathrm{AC}, \mathrm{d}}\right)$ and monthly $\left(E_{\mathrm{AC}, \mathrm{m}}\right)$ energy generated by the PV system are obtained as:

$E_{\mathrm{AC}, \mathrm{d}}=\sum_{\mathrm{t}=1}^{\mathrm{t}=24} E_{\mathrm{AC}, \mathrm{t}} \quad$ and $E_{\mathrm{AC}, \mathrm{m}}=\sum_{\mathrm{d}=1}^{N} E_{\mathrm{AC}, \mathrm{d}}$

209

210

211

212

213

214

215

216

where $N$ is the number of days in the month.

The instantaneous energy output was obtained by measuring the energy generated by the PV system after the DC/AC inverter on 5 min intervals. Fig. 6 shows the monthly total energy generated $\hat{b} y$ the PV system over the monitored period which varied be-

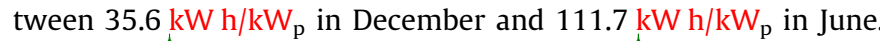
The annual total energy generated by the PV system was $885.1 \mathrm{~kW} \mathrm{~h} / \mathrm{kW}_{\mathrm{p}}$. Fig. 7 shows variation of AC power output against solar radiation. It is seen that power output had a linear relationship with solar radiation with a correlation coefficient $R^{2}$ of 0.9929 .

\subsection{Array yield}

The array yield $\left(Y_{\mathrm{A}}\right)$ is defined as the energy output from a PV array over a defined period (day, month or year) divided by its rated power and is given as [8]:

$Y_{\mathrm{A}}=\frac{E_{\mathrm{DC}}}{P_{\mathrm{PV}, \text { rated }}}$

The daily array yield $\left(Y_{\mathrm{A}, \mathrm{d}}\right)$ and monthly average daily array yield $\left(Y_{\mathrm{A}, \mathrm{m}}\right)$ are given as $[\hat{2,9] \text { : }}$

$Y_{\mathrm{A}, \mathrm{d}}=\frac{E_{\mathrm{DC}, \mathrm{d}}}{P_{\mathrm{PV}, \text { rated }}} \quad$ and $Y_{\mathrm{A}, \mathrm{m}}=\frac{1}{N} \sum_{\mathrm{d}=1}^{N} Y_{\mathrm{A}, \mathrm{d}}$

\subsection{Final yield}

The final yield is defined as the annual, monthly or daily net AC energy output of the system divided by the rated or nominal

2

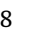

(n)


Table 4

Monthly variation of solar radiation, PV module temperature, ambient temperature.

\begin{tabular}{|c|c|c|c|c|c|c|c|}
\hline \multirow[t]{2}{*}{ Month } & \multicolumn{2}{|c|}{ Solar radiation $\left(\mathrm{W} / \mathrm{m}^{2}\right)$} & \multicolumn{3}{|c|}{ PV module temperature $\left({ }^{\circ} \mathrm{C}\right)$} & \multicolumn{2}{|c|}{ Ambient temperature $\left({ }^{\circ} \mathrm{C}\right)$} \\
\hline & Min & Max & $R^{2}$ & Min & Max & Min & Max \\
\hline January & 2.5 & 744.9 & 0.64 & -1.4 & 27.6 & 1.0 & 14.1 \\
\hline February & 0.4 & 1023.4 & & & & 1.4 & 15.6 \\
\hline March & 4.8 & 1241.9 & 0.57 & 0.4 & 40.7 & 2.7 & 20.7 \\
\hline April & 6.6 & 1184.5 & 0.76 & 2.0 & 41.6 & 6.0 & 21.3 \\
\hline May & 5.8 & 1173.1 & 0.66 & 4.5 & 44.6 & 6.8 & 23.2 \\
\hline June & 6.5 & 1105.9 & 0.72 & 9.0 & 46.9 & 10.8 & 29.5 \\
\hline July & 6.6 & 1104.4 & 0.69 & 11.5 & 41.9 & 11.9 & 24.4 \\
\hline August & 5.5 & 1153.0 & 0.64 & 10.5 & 46.4 & 12.4 & 27.9 \\
\hline September & 4.6 & 1119.6 & 0.77 & 6.7 & 46.6 & 9.2 & 24.0 \\
\hline October & 6.1 & 979.7 & 0.71 & 3.5 & 43.2 & 6.1 & 20.9 \\
\hline November & 5.6 & 834.1 & 0.60 & -1.7 & 37.4 & 0.6 & 16.6 \\
\hline December & 3.6 & 643.8 & 0.66 & -3.5 & 28.0 & 0.0 & 13.9 \\
\hline
\end{tabular}

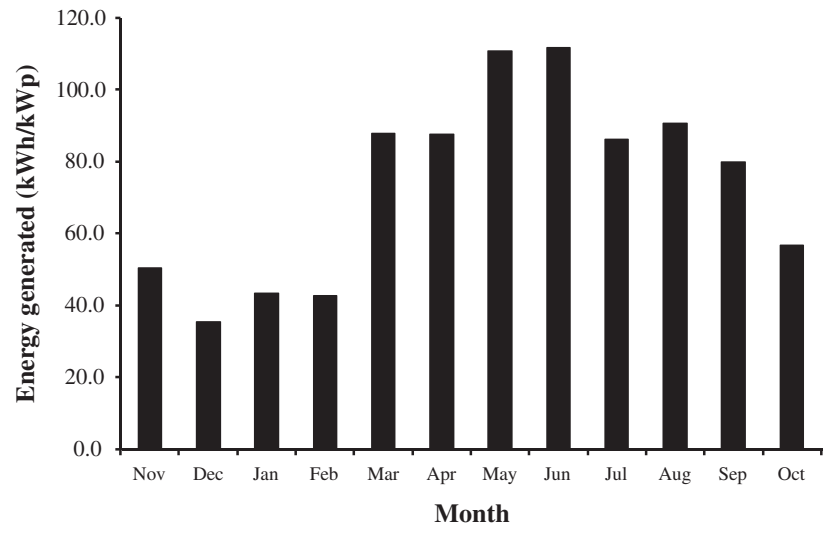

Fig. 6. Monthly total energy generated over the monitored period.

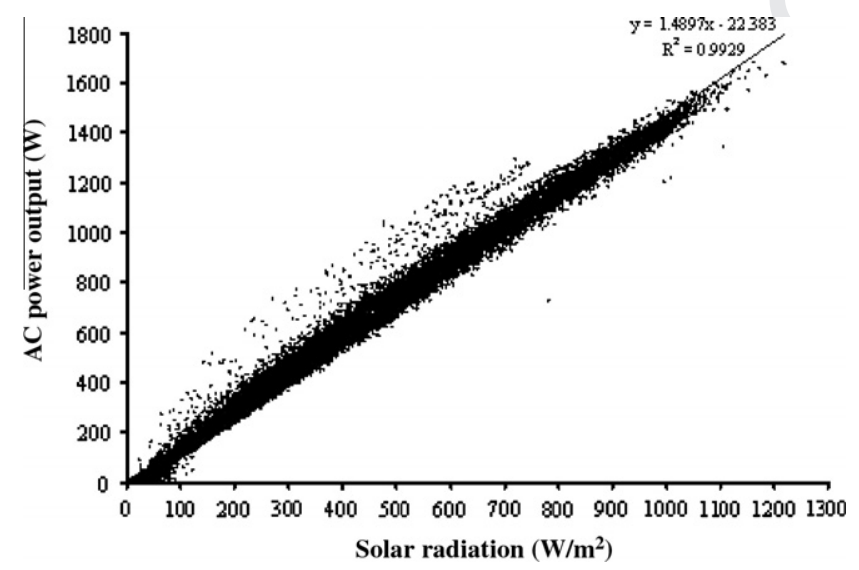

Fig. 7. AC power output against solar radiation.

power of the installed PV array at standard test conditions (STC) of $1 \mathrm{~kW} / \mathrm{m}^{2}$ solar irradiance and $25^{\circ} \mathrm{C}$ cell temperature. This is a representative figure that enable $\hat{s}$ comparison of similar PV systems in a specific geographic region. It is dependent on the type of mounting, vertical on a façade or inclined on a roof and also on the location [9]. The annual final yield is given as $[8,10]$ :

$Y_{\mathrm{F}, \mathrm{a}}=\frac{E_{\mathrm{AC}, \mathrm{a}}}{P_{\mathrm{PV}, \text { rated }}}$
The daily final yield $\left(Y_{\mathrm{F}, \mathrm{d}}\right)$ and the monthly average daily final yield $\left(Y_{\mathrm{F}, \mathrm{m}}\right)$ are given as:

$Y_{\mathrm{F}, \mathrm{d}}=\frac{E_{\mathrm{AC}, \mathrm{d}}}{P_{\mathrm{PV}, \mathrm{rated}}} \quad$ and $Y_{\mathrm{F}, \mathrm{m}}=\frac{1}{N} \sum_{\mathrm{d}=1}^{N} Y_{\mathrm{F}, \mathrm{d}}$

\subsection{Reference yield}

The reference yield is the total in-plane solar insolation $H_{t}$ $\left(\mathrm{kWh} / \mathrm{m}^{2}\right)$ divided by the array reference irradiance $\left(1 \mathrm{~kW} / \mathrm{m}^{2}\right)$. It is the number of peak sun-hours and is given as [8]:

$Y_{\mathrm{R}}=\frac{H_{\mathrm{t}}\left(\mathrm{kW} \mathrm{h} / \mathrm{m}^{2}\right)}{1\left(\mathrm{~kW} / \mathrm{m}^{2}\right)}$

Fig. 8 shows the monthly average daily PV system's final, reference and array yields over the monitored period. The monthly average daily final, reference and array yields varied between

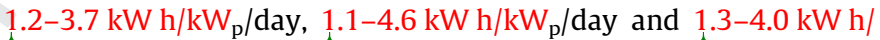
$\hat{\mathrm{k}} \mathrm{W}_{\mathrm{p}} /$ day in December and June respectively. The annual average daily final, reference and array yields were $2.41 \mathrm{~kW} \mathrm{~h} / \mathrm{kW}_{\mathrm{p}} /$ day,

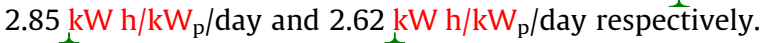

\subsection{PV module efficiency}

The instantaneous PV module conversion efficiency is calculated as [11]:

$\eta_{\mathrm{PV}}=\frac{P_{\mathrm{DC}}}{G_{\mathrm{t}} A_{\mathrm{m}}}$

The monthly PV module efficiency $\left(\eta_{\mathrm{PV}, \mathrm{m}}\right)$ is calculated as [7]:

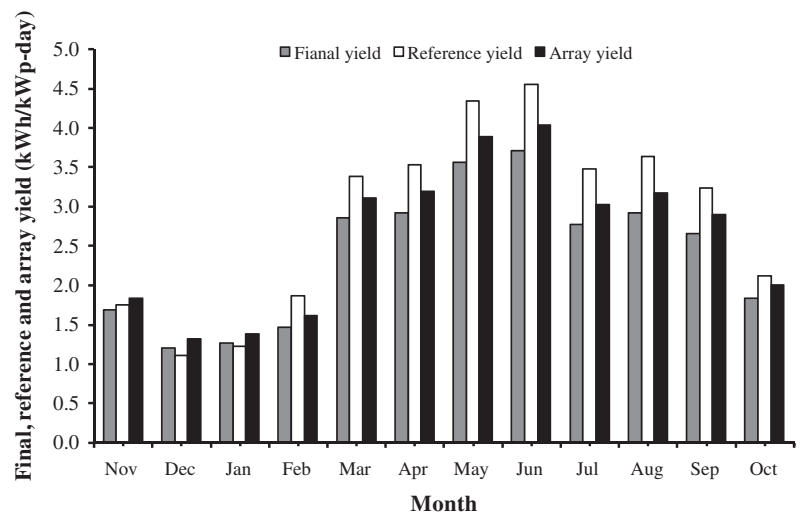

Fig. 8. Monthly average daily PV system's final yield, reference yield and array yield over the monitored period. 


\subsection{System efficiency}

The instantaneous PV system efficiency is calculated as [11]:

$$
\eta_{\mathrm{PV}}=\frac{P_{\mathrm{AC}}}{G_{\mathrm{t}} A_{\mathrm{a}}}
$$

The monthly system efficiency $\left(\eta_{\text {sys,m }}\right)$ is calculated as [7]:

$\eta_{\text {sys }, \mathrm{m}}=\left(\frac{\bar{E}_{\mathrm{AC}, \mathrm{d}}}{G_{\mathrm{t}} A_{\mathrm{a}}}\right) \times 100 \%$

\subsection{Inverter efficiency}

The instantaneous inverter efficiency is calculated as:

$\eta_{\mathrm{PV}}=\frac{P_{\mathrm{AC}}}{P_{\mathrm{DC}}}$ [7]:

The monthly inverter efficiency $\left(\eta_{\text {inv,m }}\right)$ is calculated as follows

$\eta_{\text {inv, } \mathrm{m}}=\left(\frac{\bar{E}_{\mathrm{AC}, \mathrm{d}}}{\bar{E}_{\mathrm{DC}, \mathrm{d}}}\right) \times 100 \%$

Fig. 9 shows the monthly average daily PV module, system and inverter efficiency over the monitored period. The PV module and system efficiency varied between $13.8 \%$ in February and $17.1 \%$ in December and $11.3 \%$ in February and $14.3 \%$ in December respectively. The monthly average daily inverter efficiency varied between $85.4 \%$ in December and $91.5 \%$ in June and August. The annual average daily PV module, system and inverter efficiencies were $14.9 \%, 12.6 \%$ and $89.2 \%$ respectively.

Fig. 10 shows daily variation of PV module and inverter efficiencies during three days characterized by heavily overcast $(10 / 03 /$ $09)$, clear (20/03/09) and intermittent cloud covered (21/03/09) skies. During the clear sky day, the PV module and inverter efficiency peak during the early hours after sunrise and late hours during sunset. The lowest efficiency occurs at the peak of solar radiation showing the effect of PV cell temperature increase on cell efficiency. During days with heavily overcast sky and intermittent cloud covered sky the PV module and inverter efficiencies show an irregular profile.

Fig. 11 shows variation of inverter efficiency with in-plane solar radiation. The inverter efficiency is seen to increase as the level of solar radiation increases from 0 to $200 \mathrm{~W} / \mathrm{m}^{2}$ and then remains

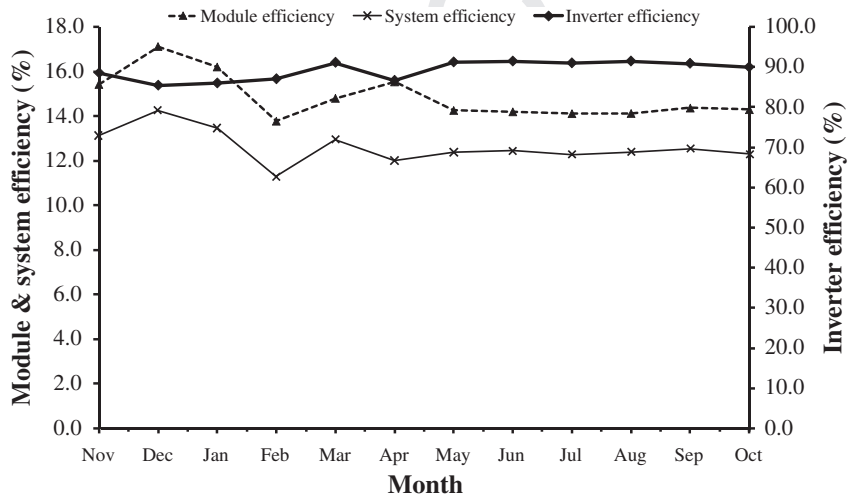

Fig. 9. Monthly average daily PV module, system and inverter efficiency over the monitored period.

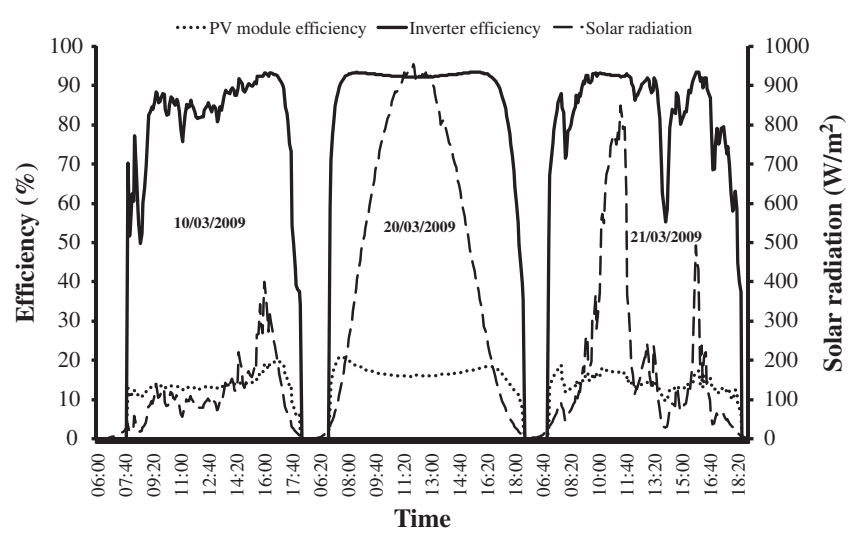

Fig. 10. Daily variation of PV module and inverter efficiency.

fairly constant between $91 \%$ and $93 \%$. The maximum inverter efficiency was $94.9 \%$ when the solar radiation value was $634.6 \mathrm{~W} / \mathrm{m}^{2}$.

\subsection{Performance ratio}

The performance ratio (PR) indicates the overall effect of losses on a PV array's normal power output depending on array temperature and incomplete utilization of incident solar radiation and system component inefficiencies or failures. The PR of a PV system indicates how close it approaches ideal performance during real operation and allows comparison of PV systems independent of location, tilt angle, orientation and their nominal rated power capacity [12,13]. The PV system efficiency is compared with the nominal efficiency of the photovoltaic generator under standard test conditions. Performance ratio is defined by the following equations as $[14,15]$ :

$\mathrm{PR}=\frac{\eta_{\text {sys }}}{\eta_{\text {STC }}}=\frac{E_{\mathrm{AC}}}{G_{\mathrm{t}}} \frac{G_{\mathrm{STC}}}{P_{\mathrm{DC}, \mathrm{STC}}}=\frac{E_{\mathrm{AC}}}{G_{\mathrm{t}} \eta_{\mathrm{STC}}}$

where

$\eta_{\text {sys }}=\frac{E_{\mathrm{AC}}}{A_{\mathrm{a}} G_{\mathrm{t}}} \quad$ and $\eta_{\mathrm{STC}}=\frac{P_{\mathrm{DC}, \mathrm{STC}}}{A_{\mathrm{a}} G_{\mathrm{STC}}}$

Performance ratio is also defined as a ratio of the final yield divided by the reference yield and it represents the total losses in the PV system when converting from DC to AC. Performance ratio is also expressed as $[8,9,16]$ :

$\mathrm{PR}=\frac{Y_{\mathrm{F}}}{Y_{\mathrm{R}}}=\frac{E_{\text {real }}}{E_{\text {ideal }}}=\eta_{\text {deg }} \eta_{\text {tem }} \eta_{\text {soil }} \eta_{\text {inv }}$

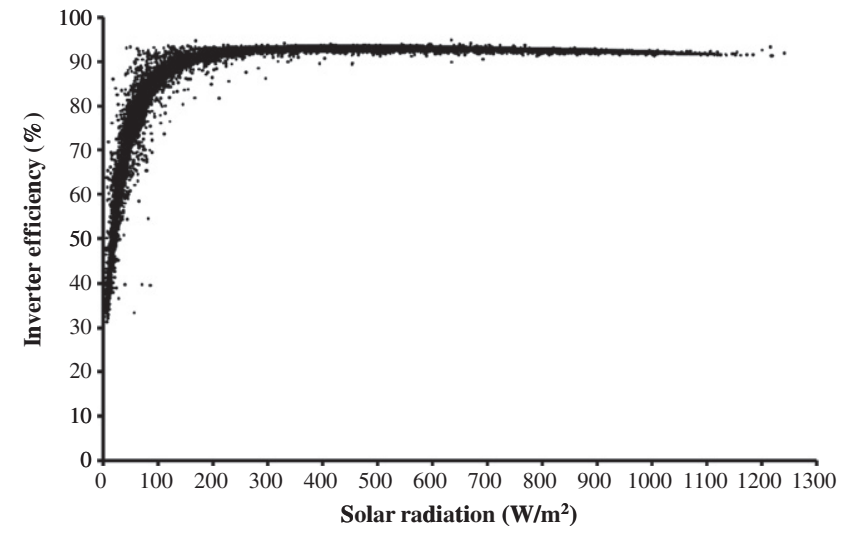

Fig. 11. Inverter efficiency against solar radiation over the monitored period. 


\subsection{Capacity factor}

The capacity factor $(\mathrm{CF})$ is a means used to present the energy delivered by an electric power generating system. If the system delivers full rated power continuously, its CF would be unity. The capacity factor $(\mathrm{CF})$ is defined as the ratio of the actual annual energy output to the amount of energy the PV system would generate if it operated at full rated power $\left(P_{\mathrm{PV} \text {,rated }}\right)$ for $24 \mathrm{~h}$ per day for a year and is given as [8]:

$\mathrm{CF}=\frac{Y_{\mathrm{F}, \mathrm{a}}}{24 \times 365}=\frac{E_{\mathrm{AC}, \mathrm{a}}}{P_{\mathrm{PV}, \text { rated }} \times 8760}=\frac{H_{\mathrm{t}} \times \mathrm{PR}}{P_{\mathrm{PV}, \text { rated }} \times 8760}$

The CF for a grid connected PV system is also given as [17]:

$\mathrm{CF}=\frac{\mathrm{h} / \text { day of "peak sun" }}{24 \mathrm{~h} / \text { day }}$

Fig. 12 shows variation of monthly average daily performance ratio and the PV system's capacity factor over the monitored period. The performance ratio varied between $72.3 \%$ in February and 91.6\% in December and the annual average performance ratio was $81.5 \%$. The monthly average daily capacity factor varied between $5.0 \%$ in December and $15.5 \%$ in June with an annual average of $10.1 \%$.

\subsection{Energy losses}

There exist a variety of sources through which energy losses occur in PV systems. These losses affect the performance of PV systems thereby justifying why it is necessary to evaluate these losses using detailed performance monitoring data. Prominent among these losses are: array capture losses, system losses, cell temperature losses, soiling and degradation. Soiling and degradation losses are more difficult to evaluate because they are small effects that occur over large fluctuations in operating conditions and are not be discussed here.

Under real operating conditions the following additional losses could be observed [18]:

- Optical reflection losses due to non-perpendicular irradiance.

- Losses due to low irradiance levels (reduction of form factor and voltage).

- Thermal losses as voltage reduction due to elevated cell temperatures.

- Reduction of output current for irradiance sun spectra with an air mass lower than AM 1.5.

- Shadowing: if a cell is shadowed in a serial string, the output current is limited by the reduced current of the shadowed cell.

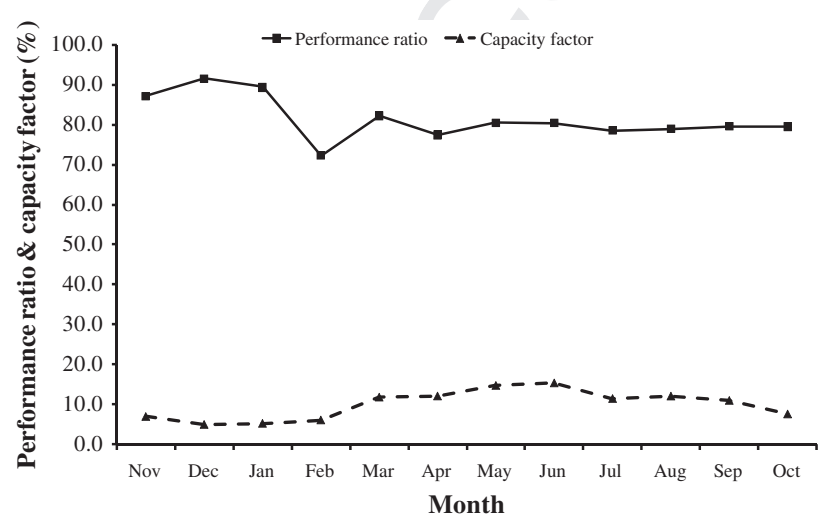

Fig. 12. Monthly average daily performance ratio and capacity factor over the monitored period.
- Power conditioning units are very often located in a small building some distance away from the generator. According to literature, the wiring losses from the PV panels to the converters are in the vicinity of $3 \%$ for most applications.

- The inverters often have high conversion efficiencies at the rated power input, but for low irradiance levels and low power input the conversion efficiency decreases. Therefore, the average conversion efficiency over a whole day could be considerably lower than the rated one.

\subsubsection{Array capture losses}

Array capture losses $\left(L_{c}\right)$ are due to the PV array losses and are given as [8]:

$L_{\mathrm{c}}=Y_{\mathrm{R}}-Y_{\mathrm{A}}$

\subsubsection{System losses} [8]:

System losses $\left(L_{\mathrm{s}}\right)$ are as a result of the inverter and are given as

$L_{\mathrm{s}}=Y_{\mathrm{A}}-Y_{\mathrm{F}}$

\subsubsection{Cell temperature losses}

As a general rule of thumb, the PV module peak power $\left(P_{\mathrm{m}}\right)$ decreases by $0.3-0.4 \%$ for every $1{ }^{\circ} \mathrm{C}$ increase in the PV cell temperature above standard test conditions (STC). Losses resulting due to the operating cell temperature varying about the temperature at STC, $L_{\mathrm{T}}$ are calculated as [19]:

$L_{\mathrm{T}}=E_{\mathrm{AT}}-E_{\mathrm{A}}$

where

$E_{\mathrm{AT}}=\frac{E_{\mathrm{A}}}{\eta_{\mathrm{tem}}}$

The temperature loss coefficient $\left(\eta_{\text {tem }}\right)$ is calculated as [8]:

$\eta_{\text {tem }}=1-\beta\left(T_{\mathrm{c}}-25\right)$

Fig. 13 shows the monthly average daily capture and system losses over the monitored period. The system losses varied between $0.12 \mathrm{~h} /$ day in December and January to $0.32 \mathrm{~h} /$ day in May. In November, December and January the PV modules experienced improvements in capture of $0.08 \mathrm{~h} /$ day, $0.21 \mathrm{~h} /$ day and $0.16 \mathrm{~h} /$ day respectively while capture losses varied between $0.12 \mathrm{~h} / \hat{\mathrm{day}}$ in October and $0.51 \mathrm{~h} /$ day in June. The maximum average daily loss due to temperature effect was $0.09 \mathrm{~h}$ /day which occurred in June. Due to low average daily module temperatures between November

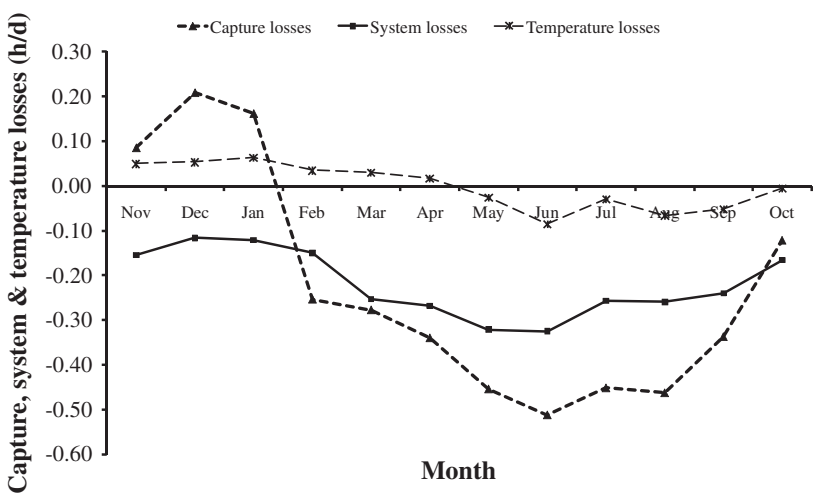

Fig. 13. Monthly daily average capture, system and temperature losses over the monitored period. 
Table 5

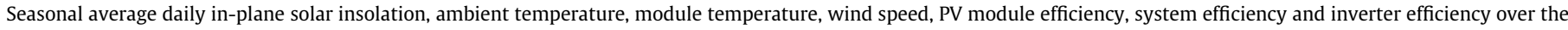
monitored period.

\begin{tabular}{|c|c|c|c|c|c|c|c|}
\hline Season & $\begin{array}{l}\text { In-plane solar insolation } \\
\left(\mathrm{kW} \mathrm{h} / \mathrm{m}^{2} \text {-day }\right)\end{array}$ & $\begin{array}{l}\text { Ambient } \\
\text { temperature }\left({ }^{\circ} \mathrm{C}\right)\end{array}$ & $\begin{array}{l}\text { PV module } \\
\text { temperature }\left({ }^{\circ} \mathrm{C}\right)\end{array}$ & $\begin{array}{l}\text { Wind speed } \\
(\mathrm{m} / \mathrm{s})\end{array}$ & $\begin{array}{l}\text { PV module } \\
\text { efficiency (\%) }\end{array}$ & $\begin{array}{l}\text { System } \\
\text { efficiency (\%) }\end{array}$ & $\begin{array}{l}\text { Inverter } \\
\text { efficiency (\%) }\end{array}$ \\
\hline Winter & 1.4 & 8.2 & 10.0 & 4.4 & 15.7 & 13.0 & 86.2 \\
\hline Spring & 3.8 & 12.6 & 17.1 & 4.2 & 14.9 & 12.5 & 89.7 \\
\hline Summer & 3.9 & 18.2 & 23.4 & 4.3 & 14.1 & 12.4 & 91.3 \\
\hline Autumn & 2.4 & 14.0 & 18.1 & 4.0 & 14.7 & 12.7 & 89.8 \\
\hline
\end{tabular}

Table 6

Seasonal energy generated, final yield, reference yield, array yield, capture losses, system losses, capacity factor and performance ratio over the monitored period.

\begin{tabular}{|c|c|c|c|c|c|c|c|c|c|}
\hline Season & $\begin{array}{l}\text { Energy generated } \\
\left(\mathrm{kW} h / \mathrm{kW}_{\mathrm{p}}\right)\end{array}$ & $\begin{array}{l}\text { Final yield } \\
\left(\mathrm{KW} \mathrm{h} / \mathrm{kW}_{\mathrm{p}} /\right. \\
\text { day })\end{array}$ & $\begin{array}{l}\text { Reference yield } \\
\text { (KW h/kW/day) }\end{array}$ & $\begin{array}{l}\text { Array yield } \\
\left(\mathrm{KW} \mathrm{h} / \mathrm{kW}_{\mathrm{p}} /\right. \\
\text { day })\end{array}$ & $\begin{array}{l}\text { Capture } \\
\text { losses (h/ } \\
\text { day) }\end{array}$ & $\begin{array}{l}\text { System } \\
\text { losses (h/ } \\
\text { day) }\end{array}$ & $\begin{array}{l}\text { Cell temp. } \\
\text { losses (h/day) }\end{array}$ & $\begin{array}{l}\text { Capacity } \\
\text { factor }(\%)\end{array}$ & $\begin{array}{l}\text { Performance } \\
\text { ratio (\%) }\end{array}$ \\
\hline Winter & 122.0 & 1.31 & 1.40 & 1.44 & $-0.04^{*}$ & 0.13 & $-0.05^{*}$ & 5.5 & 84.4 \\
\hline Spring & 286.7 & 3.12 & 3.75 & 3.40 & 0.36 & 0.28 & $-0.01^{*}$ & 13.0 & 80.1 \\
\hline Summer & 288.8 & 3.14 & 3.89 & 3.42 & 0.48 & 0.28 & 0.07 & 13.1 & 79.3 \\
\hline Autumn & 187.6 & 2.06 & 2.37 & 2.24 & 0.12 & 0.19 & 0.00 & 8.6 & 82.1 \\
\hline Average & & 2.41 & 2.85 & 2.63 & 0.23 & 0.22 & 0.00 & 10.1 & 81.5 \\
\hline
\end{tabular}

* Values represent capture and cell temperature gains.

and April, there is a positive temperature effect on the PV modules' output. On average there was no net cell temperature loss over the monitored period.

\subsection{Seasonal performance}

The seasonal average daily in-plane solar insolation, ambient temperature, module temperature, wind speed, PV module efficiency, system efficiency and inverter efficiency over the monitored period are shown in Table 5 . The results show that the maximum seasonal average in-plane solar insolation, ambient temperature, module temperature and inverter efficiency were $3.9 \mathrm{~kW} \mathrm{~h} / \mathrm{m}^{2}$-day, $18.2^{\circ} \mathrm{C}, 23.4{ }^{\circ} \mathrm{C}$ and $91.3 \%$ respectively in sum-

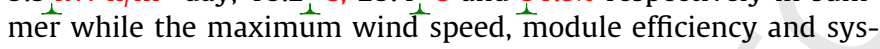

tem efficiency were $4.4 \mathrm{~m} / \mathrm{s}, 15.7 \%$ and $13.0 \%$ in winter respectively. The minimum seasonal average in-plane solar insolation, ambient temperature, module temperature and inverter efficiency were $1.4 \mathrm{kWh} / \mathrm{m}^{2}$-day, $8.2^{\circ} \mathrm{C}, \quad 10.0^{\circ} \mathrm{C}$ and $86.2 \%$ respectively in winter while the minimum wind speed ${ }^{\wedge}$ was $4.0 \mathrm{~m} / \mathrm{s}$ in autumn and the minimum module and system efficiency were $14.1 \%$ and $12.4 \%$ respectively in summer.

The seasonal energy generated, final yield, reference yield, array yield, capture losses, system losses, capacity factor and performance ratio over the monitored period are shown in Table 6 . The results show that the maximum seasonal average energy generated, final yield, reference yield, array yield, capture losses, cell temperature losses and capacity factor were $288.8 \mathrm{kWh} / \mathrm{kW}_{\mathrm{p}}$,

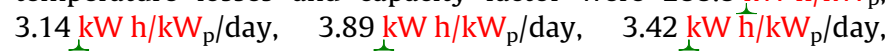

Table 7

Performance parameters for different building mounted PV systems.

\begin{tabular}{|c|c|c|c|c|c|c|c|c|}
\hline Location & $\begin{array}{l}\text { PV } \\
\text { type }\end{array}$ & $\begin{array}{l}\text { Energy output } \\
\left(\mathrm{kW} h / \mathrm{kW}_{\mathrm{p}}\right)\end{array}$ & $\begin{array}{l}\text { Final yield }(\mathrm{kW} \mathrm{h} / \\
\mathrm{kW}_{\mathrm{p}} \text {-day) }\end{array}$ & $\begin{array}{l}\text { PV module } \\
\text { efficiency (\%) }\end{array}$ & $\begin{array}{l}\text { System } \\
\text { efficiency (\%) }\end{array}$ & $\begin{array}{l}\text { Inverter } \\
\text { efficiency (\%) }\end{array}$ & $\begin{array}{l}\text { Performance } \\
\text { ratio (\%) }\end{array}$ & Reference \\
\hline Crete, Greece & PC-Si & 1336.4 & $2.0-5.1$ & - & - & - & 67.4 & [8] \\
\hline Germany & & 680 & 1.9 & - & - & - & 66.5 & [13] \\
\hline Málaga, Spain & & 1339 & 3.7 & $8.8-10.3$ & $6.1-8.0$ & $85-88$ & 64.5 & [21] \\
\hline Jaén, Spain & & 892.1 & 2.4 & 8.9 & 7.8 & 88.1 & 62.7 & [22] \\
\hline Algeria & $\begin{array}{l}\mathrm{MC}- \\
\mathrm{Si}\end{array}$ & & & 10.1 & 9.3 & 80.7 & - & [23] \\
\hline Calabria, Italy & PC-Si & 1230 & 3.4 & 7.6 & - & 84.8 & - & {$[24]$} \\
\hline Germany & & $700-1000$ & $1.9-2.7$ & - & - & - & - & [15] \\
\hline $\begin{array}{l}\text { Ballymena, Northern } \\
\text { Ireland }\end{array}$ & $\begin{array}{l}\mathrm{MC}- \\
\mathrm{Si}\end{array}$ & 616.9 & 1.7 & $7.5-10.0$ & $6.0-9.0$ & 87 & $60-62$ & [10] \\
\hline Warsaw, Poland & A-Si & 830 & 2.3 & $4.5-5.5$ & $4.0-5.0$ & $92-93$ & $60-80$ & {$[25]$} \\
\hline Castile \& Leon, Spain & $\begin{array}{l}\mathrm{MC}- \\
\mathrm{Si}\end{array}$ & 1180 & $1.4-4.8$ & 13.7 & 12.2 & 89.5 & 69.8 & {$[26]$} \\
\hline Umbertide, Italy & PC-Si & - & - & $4.0-7.0$ & $6.2-6.7$ & - & - & {$[27]$} \\
\hline UK & & 744 & - & - & - & - & 69 & [9] \\
\hline Liverpool, UK & Tiles & 777 & - & - & - & - & 72 & [9] \\
\hline Dublin, Ireland & $\begin{array}{l}\text { MC- } \\
\text { Si }\end{array}$ & 885.1 & 2.4 & 14.9 & 12.6 & 89.2 & 81.5 & $\begin{array}{l}\text { Present } \\
\text { study }\end{array}$ \\
\hline UK & $\mathrm{A}-\mathrm{Si}$ & - & - & 3.7 & 3.2 & 64.5 & 42.0 & [10] \\
\hline UK & PC-Si & - & - & - & 7.5 & - & 68.0 & [10] \\
\hline UK & - & - & - & - & 8.4 & $90-91$ & $59-61$ & [10] \\
\hline Italy & A-Si & - & - & - & - & - & 66 & [10] \\
\hline Germany & - & - & - & - & - & - & $50-81$ & [10] \\
\hline Brazil & A-Si & - & - & - & 5 & 91 & - & [10] \\
\hline Thailand & - & - & $2.9-4.0$ & - & - & $92-98$ & $70-90$ & [28] \\
\hline
\end{tabular}

PC-Si: poly-crystalline silicon, MC-Si: mono-crystalline silicon, A-Si: amorphous silicon. 
$0.48 \mathrm{~h} /$ day, $0.07 \mathrm{~h} /$ day and $13.1 \%$ respectively in summer while the maximum system losses were $0.28 \mathrm{~kW} \mathrm{~h} / \mathrm{kW}_{\mathrm{p}} /$ day in spring and summer and the maximum performance ratio was $84.4 \%$ in winter. The minimum energy generated, final yield, reference yield, array yield, capture losses, system losses, cell temperature losses and capacity factor were $122.0 \mathrm{kWh} / \mathrm{kW}_{\mathrm{p}}, \quad 1.31 \mathrm{~kW} \mathrm{~h} / \mathrm{kW}_{\mathrm{p}} / \mathrm{day}$, $1.40 \mathrm{~kW} \mathrm{~h} / \mathrm{kW}_{\mathrm{p}} /$ day, $1.44 \mathrm{~kW} \mathrm{~h} / \mathrm{kW}_{\mathrm{p}} /$ day, $-0.04 \mathrm{~h} / \mathrm{day}, 0.13 \mathrm{~h} / \mathrm{day}$,

$-0.05 \mathrm{~h} /$ day and $5.5 \%$ respectively in winter while the minimum performance ratio was $79.3 \%$ in summer. The negative capture loss in winter represents improvement in capture. The system performance parameters in spring were close to those in summer since both periods had almost the same level of average daily solar insolation. The annual average daily final yield, reference yield, array yield, capture losses, system losses, cell temperature losses, capacity factor and performance ratio were $2.41 \mathrm{~kW} \mathrm{~h} / \mathrm{kW}_{\mathrm{p}} / \mathrm{day}$, $2.85 \mathrm{~kW} \mathrm{~h} / \mathrm{kW}_{\mathrm{p}} /$ day, $2.63 \mathrm{~kW} \mathrm{~h} / \mathrm{kW}_{\mathrm{p}} /$ day, $0.23 \mathrm{~h} / \mathrm{day}, 0.22 \mathrm{~h} / \mathrm{day}$, $0.00 \mathrm{~h} /$ day, $10.1 \%$ and $81.5 \%$ respectively.

\section{Comparative PV system performance}

To be able to compare operating results from different PV systems, the specific yield in $\mathrm{kWh} / \mathrm{kW}_{\mathrm{p}} /$ year is calculated as well as the performance ratio. The full-load hours or the final yield $\left(Y_{\mathrm{F}}\right)$ is also a very important factor for comparing PV systems. The full-load hours is the ratio of the yield over a particular time period to the nominal power of the generator. The reference time-frame can be a day, week, month or year and is given as [16]:

$$
Y_{\mathrm{F}}=\frac{E_{\text {real }}}{P_{\mathrm{PV}, \text { rated }}}
$$

The annual average daily final yield of other monitored PV systems previously reported include: Germany, $1.8 \mathrm{~kW} \mathrm{~h} / \mathrm{kW}_{\mathrm{p}} /$ day;

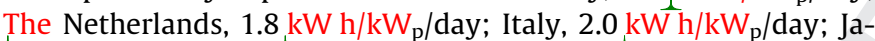
pan, $2.7 \mathrm{kWh} / \mathrm{kW}_{\mathrm{p}} /$ day and Israel, $3.5 \mathrm{~kW} \mathrm{~h} / \mathrm{kW}_{\mathrm{p}} /$ day [20]. Table 7 shows performance parameters for different building mounted PV systems. The annual average daily final yield of the PV system in this study was $2.4 \mathrm{~kW} \mathrm{~h} / \mathrm{kW}_{\mathrm{p}} /$ day which was higher than those reported in Germany, Poland and Northern Ireland. It is comparable to results from some parts of Spain but it was lower than the reported yields in Italy and southern parts of Spain. The PV system had the highest PV module efficiency, system efficiency and performance ratio compared to the other systems. High wind speeds and low ambient temperature at the test location provided suitable conditions for PV systems.

\section{Conclusion}

A $1.72 \mathrm{~kW}_{\mathrm{p}}$ grid connected PV system installed in Dublin, Ireland was monitored between November 2008 and October 2009 and its performance parameters were evaluated on monthly, seasonal and annual basis. Site data during the monitored period showed that annual average daily PV module in-plane solar insolation, ambient temperature, PV module temperature and wind speed were $2.9 \mathrm{kWh} / \mathrm{m}^{2} /$ day, $13.3^{\circ} \mathrm{C}, \quad 17.2^{\circ} \mathrm{C}$ and $4.2 \mathrm{~m} / \mathrm{s}$ respectively.

The monthly total energy generated varied between $35.6 \mathrm{~kW} \mathrm{h/}$ $\mathrm{kW}_{\mathrm{p}}$ in December and $111.7 \mathrm{~kW} \mathrm{~h} / \mathrm{kW}_{\mathrm{p}}$ in June while the annual total energy generated was $8 \hat{8} 5.1 \mathrm{~kW} \mathrm{~h} / \mathrm{kW}_{\mathrm{p}}$. The monthly average daily final, reference and array yields varied between $1.2 \mathrm{~kW} \mathrm{~h} /$ $\mathrm{kW}_{\mathrm{p}} /$ day and $3.7 \mathrm{kWh} / \mathrm{kW}_{\mathrm{p}} /$ day, $1.1 \mathrm{kWh} / \mathrm{kW}_{\mathrm{p}} /$ day and 4.6 $\mathrm{kWh} / \mathrm{kW}_{\mathrm{p}} /$ day and $1.3 \mathrm{kWh} / \mathrm{kW}_{\mathrm{p}} /$ day ând $4.0 \mathrm{kWh} / \mathrm{kW}_{\mathrm{p}} /$ day in December and June respectively. The annual average daily final yield, reference yield and array yield were $2.41 \mathrm{~kW} \mathrm{~h} / \mathrm{kW}_{\mathrm{p}} /$ day,

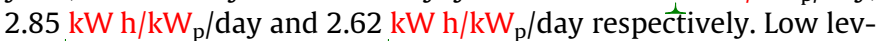
els of solar insolation during $\mathrm{w}$ winter resulted in low final yield. The
PV module and system efficiencies varied between $13.8 \%$ in February and $17.1 \%$ in December and $11.3 \%$ in February and $14.3 \%$ in December respectively. The monthly average daily inverter efficiency varied between $85.4 \%$ in December and $91.5 \%$ in June and August. The annual average daily module, system and inverter efficiencies were $14.9 \%, 12.6 \%$ and $89.2 \%$ respectively.

The performance ratio varied between $72.3 \%$ in February and $91.6 \%$ in December and the annual average performance ratio was $81.5 \%$. The monthly average daily capacity factor varied between $5.0 \%$ in December and $15.5 \%$ in June with an annual average of $10.1 \%$. The system losses varied between $0.12 \mathrm{~h} /$ day in December and January and $0.32 \mathrm{~h}$ /day in May. In November, December and January the $\widehat{P V}$ modules experienced improvements in capture of $0.08,0.21$ and $0.16 \mathrm{~h}$ /day respectively while capture losses varied between $0.12 \mathrm{~h} /$ day in October and $0.51 \mathrm{~h} /$ day in June. The maximum average daily loss due to temperature effect was $0.09 \mathrm{~h} /$ day and occurred in June. The system losses varied between $0.12 \mathrm{~h} /$ day in December and January and $0.32 \mathrm{~h} /$ day in May. In November, December and January the PV modules experienced improvements in capture of $0.08,0.21$ and $0.16 \mathrm{~h} /$ day respectively while capture losses varied between $0.12 \mathrm{~h} /$ day in October and $0.51 \mathrm{~h} /$ day in June. The maximum average daily loss due to temperature effect was $0.09 \mathrm{~h} /$ day and occurred in June.

Comparison of results from this study with those obtained from other studies internationally revealed that the PV system's annual

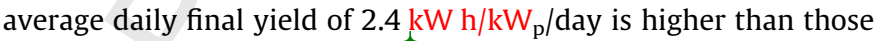
reported in Germany, Poland and Northern Ireland. It is comparable to results from some parts of Spain but it is lower than the reported yields in most parts of Italy and Spain. The PV system has the highest PV module efficiency, system efficiency and performance ratio compared to the other reported systems. Despite low insolation levels, high average wind speeds and low ambient temperature improve Ireland's suitability.

\section{References}

[1] Nawaz I, Tiwari GN. Embodied energy analysis of photovoltaic (PV) system based on macro- and micro-level. Energy Policy 2006;34(17):3144-52.

[2] European photovoltaic industry association and green peace. Solar generation V. 2008. <http://www.epia.org>.

[3] Renewable Energy Policy Framework (REN21). Renewables global status report: 2009 update, Paris; 2009

[4] Eurobserv'er, Photovoltaic barometer. March 2009.

[5] Sustainable Energy Ireland. Micro and small scale-generation pilot trial consultation $<$ http://www sei.ie/index asp?locID=1708\&docID=-1>.

[6] Department of Environment Heritage and Local Government. People power. <http://www.dcenr.gov.ie/Press+Releases/People+power+-+Minister+Ryan+ announces+incentives+for+micro-generation.htm>.

[7] Mondol JD, Yohanis YG, Norton B. The effect of low insolation conditions and inverter oversizing on long-term performance of a grid-connected photovoltaic system. Prog Photovolt Res Appl 2007;15:353-68.

[8] Kymakis E, Kalykakis S, Papazoglou TM. Performance analysis of a grid connected photovoltaic park on the island of Crete. Energy Convers Manage 2009;50(3):433-8.

[9] Photovoltaic Power Systems Programme, Cost and performance trends in gridconnected photovoltaic systems and case studies. IEA-PVPS T2-06:2007.

[10] Mondol JD et al. Long term performance analysis of a grid connected photovoltaic system in Northern Ireland. Energy Convers Manage 2006:47(18-19):2925-47.

[11] Duffie JA, Beckman WA. Solar engineering of thermal processes. New York: Wiley; 1991.

[12] Blaesser G. PV system measurements and monitoring the European experience. Sol Energy Mater Sol Cells 1997;47(1-4):167-76.

[13] Decker B, Jahn U. Performance of 170 grid connected PV plants in Northern Germany-Analysis of yields and optimization potentials. Solar Energy 59(46): $127-33$.

[14] Nakagami H et al. Performance of residential PV system under actual field conditions in western part of Japan. In: International solar energy conference, 2003. Hawaii, USA.

[15] Eicker U. Solar technologies for buildings. England: John Wiley and Sons; 2003.

[16] The German Solar Energy Society, planning and installing photovoltaic systems: a guide for installers, architects and engineers. UK: James and James; 2006

[17] Masters GM. Renewable and efficient electric power systems. New Jersey: John Wiley and Sons; 2004. 
[23] Benatiallah A, Mostefaou R, Bradja K. Performance of photovoltaic solar system in Algeria. Desalination 2007;209(1-3):39-42.

systems. Berlin: Springer; 2006.

[19] Ueda $Y$ et al. Performance analysis of various system configurations on gridconnected residential PV systems. Sol Energy Mater Sol Cells 2009;93(67):945-9.

[20] Jahn U et al. International energy agency TASK II database on photovoltaic power systems: statistical and analytical evaluation of PV operational data. In: 2nd World conference on photovoltaic solar energy conversion, 1998. Vienna, Austria.

[21] Sidrach-de-Cardona M, Mora López L. Performance analysis of a gridconnected photovoltaic system. Energy 1999;24(2):93-102.

[22] Drif $\mathrm{M}$ et al. Univer project. A grid connected photovoltaic system of at Jaén University. Overview and performance analysis. Sol Energy Mater Sol Cells 2007;91(8):670-83.
[24] Cucumo M et al. Performance analysis of a $3 \mathrm{~kW}$ grid-connected photovoltaic plant. Renew Energy 2006;31(8):1129-38.

[25] Pietruszko SM, Gradzki M. Performance of a grid connected small PV system in Poland. Appl Energy 74(1-2): 177-84.

[26] Miguel AD et al. Performance analysis of a grid-connected PV system in a rural site in the northwest of Spain. In: World renewable energy congress VII 2002. Cologne, Germany; 2002.

[27] Ubertini S, Desideri U. Performance estimation and experimental measurements of a photovoltaic roof. Renew Energy 2003;28(12):833-1850.

[28] Chokmaviroj S, Wattanapong R, Suchart Y. Performance of a $500 \mathrm{kWp}$ gric connected photovoltaic system at Mae Hong Son Province, Thailand. Renew Energy 2006;31:19-28. 